\title{
Halobacillus seohaensis sp. nov., isolated from a marine solar saltern in Korea
}

\author{
Jung-Hoon Yoon, So-Jung Kang and Tae-Kwang Oh
}

Correspondence

Jung-Hoon Yoon

jhyoon@kribb.re.kr
Korea Research Institute of Bioscience and Biotechnology (KRIBB), PO Box 115, Yusong, Taejon, Republic of Korea

\begin{abstract}
A Gram-positive or Gram-variable, motile, moderately halophilic, rod-shaped bacterial strain, ISL $-50^{\top}$, was isolated from a marine solar saltern in Korea and subjected to a polyphasic taxonomic study. Strain ISL-50 $0^{\top}$ grew optimally at $\mathrm{pH} 7.0-8.0$ and $37{ }^{\circ} \mathrm{C}$ in the presence of $8 \%$ $(\mathrm{w} / \mathrm{v}) \mathrm{NaCl}$. Phylogenetic analyses based on 16S rRNA gene sequences showed that strain ISL-50 ${ }^{\top}$ belonged to the genus Halobacillus. Strain ISL- $50^{\top}$ exhibited $16 \mathrm{~S}$ rRNA gene sequence similarity values of 95.3-98.2\% with respect to the type strains of recognized Halobacillus species. The cell-wall peptidoglycan was based on meso-diaminopimelic acid, the predominant menaquinone was MK-7 and the major fatty acids were anteiso- $C_{15: 0}$ and anteiso- $C_{17: 0}$. The DNA G +C content was 39.3 mol\%. DNA-DNA relatedness data and differential phenotypic properties revealed that strain ISL $-50^{\top}$ was distinguishable from the recognized Halobacillus species. On the basis of phenotypic, chemotaxonomic, phylogenetic and genetic data, strain ISL-50 ${ }^{\top}$ represents a novel species of the genus Halobacillus, for which the name Halobacillus seohaensis sp. nov. is proposed. The type strain is ISL $-50^{\top}\left(=\mathrm{KCTC} 13145^{\top}=\mathrm{CCUG} 54358^{\top}\right)$.
\end{abstract}

The genus Halobacillus was created by Spring et al. (1996) and, at the time of writing, comprises 14 species with validly published names: Halobacillus halophilus, H. litoralis and H. trueperi (Spring et al., 1996), H. salinus (Yoon et al., 2003), H. karajensis (Amoozegar et al., 2003), H. locisalis (Yoon et al., 2004), $H$. aidingensis and $H$. dabanensis (Liu et al., 2005), H. yeomjeoni (Yoon et al., 2005), H. campisalis (Yoon et al., 2007), H. profundi and H. kuroshimensis (Hua et al., 2007), H. faecis (An et al., 2007b) and H. mangrovi (Soto-Ramírez et al., 2008). The genus Halobacillus is differentiated from phylogenetically related genera of the family Bacillaceae by having cell-wall peptidoglycan based on L-Orn-D-Asp (Spring et al., 1996; Nunes et al., 2006; An et al., 2007a). However, H. campisalis, which was described recently, was found to contain meso-diaminopimelic acid (meso-DAP) instead of L-ornithine as the diamino acid in the cell-wall peptidoglycan (Yoon et al., 2007). In this study, we report on the taxonomic characterization of another Halobacillus-like bacterial strain, ISL- $50^{\mathrm{T}}$, that contains meso-DAP as the diamino acid in the cell-wall peptidoglycan.

Strain ISL- $50^{\mathrm{T}}$ was isolated from a sediment collected from a marine solar saltern at Byunsan, Korea, by means of the dilution-plating technique at $30{ }^{\circ} \mathrm{C}$ on marine agar 2216

Abbreviation: meso-DAP, meso-diaminopimelic acid.

The GenBank/EMBL/DDBJ accession number for the 16S rRNA gene sequence of strain ISL-50 ${ }^{\top}$ is EF612763.

A transmission electron micrograph of a cell of strain ISL $-50^{\top}$ is available with the online version of this paper.
(MA; Difco) supplemented with $8 \%(\mathrm{w} / \mathrm{v}) \mathrm{NaCl}$. The type strains of 13 Halobacillus species were used as reference strains for DNA-DNA hybridization. H. halophilus KCTC $3685^{\mathrm{T}}$, H. litoralis KCTC $3687^{\mathrm{T}}$, H. trueperi KCTC $3686^{\mathrm{T}}$ and H. faecis KCTC $13121^{\mathrm{T}}$ were obtained from the Korean Collection for Type Cultures (Taejon, Korea), H. karajensis DSM $14948^{\mathrm{T}}$, H. profundi DSM $18394^{\mathrm{T}}$ and H. kuroshimensis DSM $18393^{\mathrm{T}}$ were obtained from the Deutsche Sammlung von Mikroorganismen und Zellkulturen (DSMZ; Braunschweig, Germany), H. salinus HSL-3 ${ }^{\mathrm{T}}, H$. locisalis MSS- $155^{\mathrm{T}}, \quad H$. yeomjeoni MSS $-402^{\mathrm{T}}$ and $H$. campisalis ASL- $17^{\mathrm{T}}$ were obtained from our previous studies (Yoon et al., 2003, 2004, 2005, 2007) and $H$. aidingensis JCM $12771^{\mathrm{T}}$ and $H$. dabanensis JCM $12772^{\mathrm{T}}$ were obtained from the Japan Collection of Microorganisms (Saitama, Japan).

Morphological, physiological and biochemical characteristics of strain ISL- $50^{\mathrm{T}}$ were investigated by using routine cultivation on MA supplemented with $6 \%(\mathrm{w} / \mathrm{v}) \mathrm{NaCl}$ at $37{ }^{\circ} \mathrm{C}$. Cell morphology was examined by using light microscopy (E600; Nikon) and transmission electron microscopy. Flagellation was determined by using a Philips CM-20 transmission electron microscope with cells from exponentially growing cultures. For this purpose, the cells were negatively stained with $1 \%(\mathrm{w} / \mathrm{v})$ phosphotungstic acid and the grids were examined after being airdried. Growth under anaerobic conditions was determined after incubation in a Forma anaerobic chamber on MA supplemented with $6 \%(\mathrm{w} / \mathrm{v}) \mathrm{NaCl}$ and on MA supplemented with $6 \%(\mathrm{w} / \mathrm{v}) \mathrm{NaCl}$ and potassium nitrate $(0.1 \%$, 
w/v), both of which had been prepared anaerobically using nitrogen. The $\mathrm{pH}$ range for growth was determined in marine broth 2216 (MB; Difco) supplemented with $6 \%$ $(\mathrm{w} / \mathrm{v}) \mathrm{NaCl}$ and $1 \%(\mathrm{w} / \mathrm{v})$ L-malate adjusted to various $\mathrm{pH}$ values ( $\mathrm{pH} 4.5-9.5$, using increments of $0.5 \mathrm{pH}$ units) by the addition of $\mathrm{HCl}, \mathrm{NaHCO}_{3}$ or $\mathrm{Na}_{2} \mathrm{CO}_{3}$. Growth in the absence of $\mathrm{NaCl}$ was investigated by using trypticase soy broth, using supplementation with $0.45 \% \quad(\mathrm{w} / \mathrm{v})$ $\mathrm{MgCl}_{2} \cdot 6 \mathrm{H}_{2} \mathrm{O}$ and $1 \%(\mathrm{w} / \mathrm{v})$ L-malate, prepared according to the Difco formula except that $\mathrm{NaCl}$ was excluded. Growth at different $\mathrm{NaCl}$ concentrations [2-25\% (w/v), using $1 \%$ increments] was investigated in $\mathrm{MB}$ supplemented with $1 \%(\mathrm{w} / \mathrm{v})$ L-malate. Growth at various temperatures $\left(4,10,20,25\right.$ and $30-40{ }^{\circ} \mathrm{C}$, using $1{ }^{\circ} \mathrm{C}$ increments) was measured on MA supplemented with $6 \%$ $(\mathrm{w} / \mathrm{v}) \mathrm{NaCl}$. Catalase and oxidase activities and hydrolysis of casein, starch and Tweens 20,40,60 and 80 were determined as described by Cowan \& Steel (1965). Hydrolysis of hypoxanthine, tyrosine and xanthine was tested on MA supplemented with $6 \%(\mathrm{w} / \mathrm{v}) \mathrm{NaCl}$, using the substrate concentrations described by Cowan \& Steel (1965). Hydrolysis of aesculin, gelatin and urea and reduction of nitrate were investigated as described by Lanyi (1987), using artificial seawater supplemented with $6 \%(\mathrm{w} / \mathrm{v}) \mathrm{NaCl}$. The artificial seawater contained the following [(1 distilled water $)^{-1}$ ]: $23.6 \mathrm{~g} \mathrm{NaCl}, 0.64 \mathrm{~g} \mathrm{KCl}$, $4.53 \mathrm{~g} \mathrm{MgCl}_{2} .6 \mathrm{H}_{2} \mathrm{O}$, $5.94 \mathrm{~g} \mathrm{MgSO}_{4} .7 \mathrm{H}_{2} \mathrm{O}$ and $1.3 \mathrm{~g}$ $\mathrm{CaCl}_{2} \cdot 2 \mathrm{H}_{2} \mathrm{O}$ (Bruns et al., 2001). Susceptibility to antibiotics was determined on MA plates supplemented with $6 \%(\mathrm{w} / \mathrm{v}) \mathrm{NaCl}$ using antibiotic discs (Advantec) with the following concentrations ( $\mu \mathrm{g}$, unless indicated otherwise): polymyxin B, $100 \mathrm{U}$; streptomycin, 50; penicillin G, $20 \mathrm{U}$; chloramphenicol, 100; ampicillin, 10; cephalothin, 30; gentamicin, 30; novobiocin, 5; tetracycline, 30; kanamycin, 30; lincomycin, 15; oleandomycin, 15; neomycin, 30; carbenicillin, 100. Acid production from carbohydrates was tested as described by Leifson (1963) using supplementation with $7 \%(\mathrm{w} / \mathrm{v}) \mathrm{NaCl}$. Utilization of various substrates for growth was determined as described by Baumann \& Baumann (1981), using supplementation with $7 \%(\mathrm{w} / \mathrm{v}) \mathrm{NaCl}, 2 \%(\mathrm{v} / \mathrm{v})$ Hutner's mineral salts solution (Cohen-Bazire et al., 1957) and $1 \%(\mathrm{v} / \mathrm{v})$ vitamin solution (Staley, 1968). Enzyme activities were determined by using the API ZYM system (bioMérieux).

Cell biomass for DNA extraction and for the analysis of cell-wall and isoprenoid quinones was obtained from cells grown in $\mathrm{MB}$ supplemented with $6 \%(\mathrm{w} / \mathrm{v}) \mathrm{NaCl}$ and $1 \%$ (w/v) L-malate at $37{ }^{\circ} \mathrm{C}$. Chromosomal DNA was isolated and purified according to the method described by Yoon et al. (1996), with the exception that RNase T1 was used in combination with RNase A to minimize the contamination of RNA. The 16S rRNA gene was amplified by means of a PCR with two universal primers, as described previously (Yoon et al., 1998). Sequencing of the amplified 16S rRNA gene and the phylogenetic analysis were performed as described by Yoon et al. (2003). The isomer type of the diamino acid in the cell-wall peptidoglycan was analysed by using TLC according to the method described by Komagata \& Suzuki (1987). Preparation of whole-cell hydrolysates and determination of the isomer type of the diamino acid were also performed at the DSMZ, using TLC and the solvent system of Rhuland et al. (1955). Isoprenoid quinones were analysed as described by Komagata \& Suzuki (1987), using reversed-phase HPLC. For analysis of cellular fatty acids, cell mass from strain ISL- $50^{\mathrm{T}}$ was harvested from agar plates after cultivation for 7 days at $37{ }^{\circ} \mathrm{C}$ on MA supplemented with $6 \%(\mathrm{w} / \mathrm{v}) \mathrm{NaCl}$. Fatty acids were extracted and fatty acid methyl esters were prepared according to the standard protocol of the MIDI/ Hewlett Packard Microbial Identification System (Sasser, 1990). The DNA G $+C$ content was determined by using the method of Tamaoka \& Komagata (1984) with the modification that the DNA was hydrolysed by using nuclease P1 (Sigma) and the resultant nucleotides were analysed by reversed-phase HPLC. DNA-DNA hybridization was performed fluorometrically by using the method of Ezaki et al. (1989) with photobiotin-labelled DNA probes and microdilution wells. Hybridization was performed with five replications for each sample. The highest and lowest values obtained for each sample were excluded, and the means of the remaining three values were quoted as the DNA-DNA relatedness values.

Morphological, cultural, physiological and biochemical characteristics of strain ISL $-50^{\mathrm{T}}$ are given in the species description or in Table 1. A transmission electron micrograph of a cell of strain ISL- $50^{\mathrm{T}}$ is available as Supplementary Fig. S1 in IJSEM Online. The almostcomplete 16S rRNA gene sequence of strain ISL- $50^{\mathrm{T}}$ determined in this study comprised $1522 \mathrm{nt}$, representing approximately $96 \%$ of the Escherichia coli $16 \mathrm{~S}$ rRNA gene sequence. Comparative 16S rRNA gene sequence analysis revealed that strain ISL- $50^{\mathrm{T}}$ has the closest phylogenetic affiliation with the genus Halobacillus. In a phylogenetic tree constructed by using the neighbour-joining algorithm, strain $\mathrm{ISL}-50^{\mathrm{T}}$ fell within the radiation of the cluster comprising Halobacillus species, forming a cluster with the type strains of $H$. campisalis and H. halophilus (Fig. 1). The relationships among strain ISL- $50^{\mathrm{T}}, H$. campisalis and $H$. halophilus were also maintained in trees based on the maximum-likelihood and maximum-parsimony algorithms (Fig. 1). Strain ISL-50 $0^{\mathrm{T}}$ exhibited $16 \mathrm{~S}$ rRNA gene sequence similarity values of $95.3-98.2 \%$ with respect to the type strains of Halobacillus species and values $<95.6 \%$ with respect to other species used in the phylogenetic analysis.

Strain ISL $-50^{\mathrm{T}}$ possessed cell-wall peptidoglycan containing meso-DAP as the diagnostic diamino acid. The predominant isoprenoid quinone detected in strain ISL $-50^{\mathrm{T}}$ was MK-7; minor amounts (approx. 3\%) of MK-6 and MK-8 were also present. The fatty acid profile of strain ISL- $50^{\mathrm{T}}$ was composed of the following (each constituting $>0.5 \%$ of total fatty acids): branched fatty acids anteiso- $\mathrm{C}_{15: 0}$ $(69.2 \%)$, anteiso- $\mathrm{C}_{17: 0}(13.5 \%)$, iso- $\mathrm{C}_{16: 0}(5.6 \%)$, iso$\mathrm{C}_{15: 0}(4.6 \%)$, iso- $\mathrm{C}_{14: 0}(2.5 \%)$, iso- $\mathrm{C}_{17: 0}(0.8 \%)$ and anteiso- $\mathrm{C}_{17: 1}(0.5 \%)$ and straight-chain fatty acids $\mathrm{C}_{15: 0}$ 
Table 1. Differential phenotypic properties of Halobacillus species

Taxa: 1, strain ISL-50 ${ }^{\mathrm{T}}$; 2, H. halophilus, data from Claus et al. (1983) and Spring et al. (1996); 3, H. campisalis, data from Yoon et al. (2007); 4, H. trueperi, data from Spring et al. (1996); 5, H. litoralis, data from Spring et al. (1996); 6, H. salinus, data from Yoon et al. (2003); 7, H. karajensis, data from Amoozegar et al. (2003); 8, H. locisalis, data from Yoon et al. (2004); 9, H. dabanensis, data from Liu et al. (2005); 10, H. aidingensis, data from Liu et al. (2005); 11, H. yeomjeoni, data from Yoon et al. (2005); 12, H. profundi, data from Hua et al. (2007); 13, H. kuroshimensis, data from Hua et al. (2007); 14, $\mathrm{H}$. faecis, data from An et al. (2007b). All were positive for catalase and oxidase and negative for nitrate reduction (not determined for $\mathrm{H}$. karajensis), urease, anaerobic growth and hydrolysis of tyrosine (not determined for H. karajensis). +, Positive reaction; -, negative reaction; w, weakly positive reaction; v, variable reaction; ND, not determined.

\begin{tabular}{|c|c|c|c|c|c|c|c|c|c|c|c|c|c|c|}
\hline Characteristic & 1 & 2 & 3 & 4 & 5 & 6 & 7 & 8 & 9 & 10 & 11 & 12 & 13 & 14 \\
\hline Cell morphology & Rods & $\begin{array}{c}\text { Cocci or } \\
\text { oval-shaped }\end{array}$ & $\begin{array}{c}\text { Cocci or } \\
\text { oval-shaped }\end{array}$ & Rods & Rods & Rods & Rods & Rods & Rods & Rods & $\begin{array}{c}\text { Rods or long } \\
\text { filamentous } \\
\text { rods }\end{array}$ & Rods & Rods & Rods \\
\hline Gram staining & $+(\mathrm{v})$ & + & $+(\mathrm{v})$ & + & + & $+(\mathrm{v})$ & + & $+(\mathrm{v})$ & + & + & $+(\mathrm{v})$ & + & + & + \\
\hline Spore shape & Ellipsoidal & Spherical & Spherical & $\begin{array}{l}\text { Ellipsoidal } \\
\text { or spherical }\end{array}$ & $\begin{array}{l}\text { Ellipsoidal } \\
\text { or spherical }\end{array}$ & Ellipsoidal & $\begin{array}{l}\text { Ellipsoidal } \\
\text { or spherical }\end{array}$ & Ellipsoidal & Ellipsoidal & Ellipsoidal & Ellipsoidal & $\begin{array}{l}\text { Ellipsoidal } \\
\text { or spherical }\end{array}$ & $\begin{array}{l}\text { Ellipsoidal } \\
\text { or spherical }\end{array}$ & $\begin{array}{l}\text { Ellipsoidal } \\
\text { or spherical }\end{array}$ \\
\hline Colony colour & $\begin{array}{c}\text { Yellowish- } \\
\text { white }\end{array}$ & Orange & Light yellow & Orange & Orange & $\begin{array}{c}\text { Pale orange- } \\
\text { yellow }\end{array}$ & $\begin{array}{c}\text { Cream or } \\
\text { white }\end{array}$ & $\begin{array}{c}\text { Light orange- } \\
\text { yellow }\end{array}$ & $\begin{array}{c}\text { Cream to } \\
\text { orange }\end{array}$ & Orange & Light yellow & Pale yellow & $\begin{array}{r}\text { Yellow- } \\
\text { orange }\end{array}$ & Orange \\
\hline $\begin{array}{l}\text { Maximum temp. } \\
\text { for growth }\left({ }^{\circ} \mathrm{C}\right)\end{array}$ & 38 & 40 & 41 & 44 & 43 & 45 & 49 & 42 & 50 & 40 & 48 & 47 & 48 & 45 \\
\hline \multicolumn{15}{|l|}{ Growth at: } \\
\hline $4{ }^{\circ} \mathrm{C}$ & + & - & + & - & - & - & - & - & - & - & - & - & - & - \\
\hline pH 5.0 & - & - & - & - & - & + & - & + & + & - & - & - & - & - \\
\hline Casein & + & + & + & - & - & + & + & - & + & + & + & + & + & $\mathrm{ND}$ \\
\hline Gelatin & - & + & - & + & + & + & + & - & - & + & + & - & + & + \\
\hline Starch & + & + & + & - & - & - & + & + & + & + & - & + & + & $\mathrm{ND}$ \\
\hline Tween 80 & - & - & - & - & - & + & - & + & - & - & + & + & + & $\mathrm{ND}$ \\
\hline \multicolumn{15}{|c|}{ Acid production from: } \\
\hline D-Fructose & - & - & + & + & + & + & + & + & + & + & - & + & + & + \\
\hline D-Galactose & - & - & + & + & - & $\mathrm{w}$ & - & - & - & - & - & - & - & + \\
\hline Maltose & - & - & - & + & + & + & + & - & + & + & + & + & + & + \\
\hline Sucrose & + & - & + & + & + & + & - & + & + & + & + & + & + & + \\
\hline D-Xylose & + & - & - & - & + & - & - & - & + & - & - & + & - & - \\
\hline
\end{tabular}




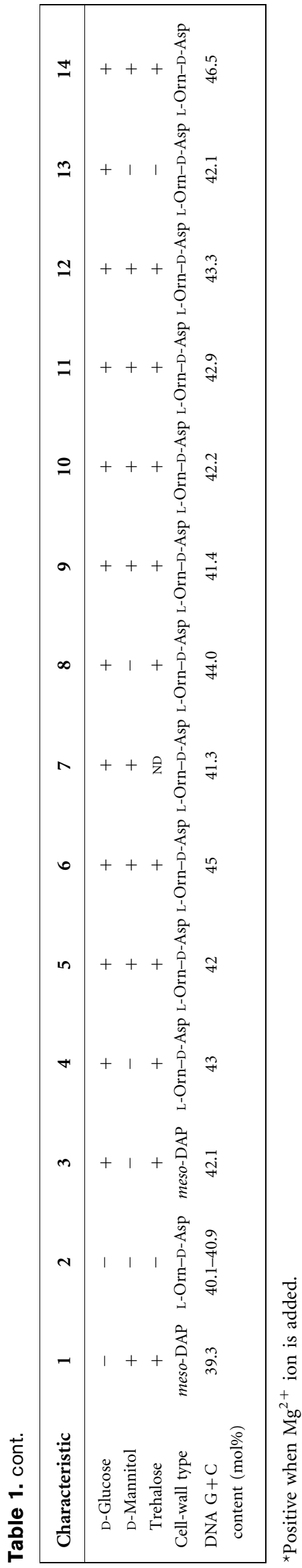

$(1.8 \%)$ and $\mathrm{C}_{16: 0}(1.4 \%)$. This fatty acid profile is similar to those of Halobacillus species, although there are differences in the proportions of some fatty acids, probably because of differences in cultivation conditions and extraction procedures (Liu et al., 2005; Yoon et al., 2005, 2007). The DNA G $+C$ content of strain ISL- $50^{\mathrm{T}}$ was $39.3 \mathrm{~mol} \%$. These chemotaxonomic properties are sufficient to support the result of the phylogenetic classification, i.e. that strain ISL- $50^{\mathrm{T}}$ could be a member of the genus Halobacillus, although there is a difference in the type of diagnostic diamino acid between strain ISL- $50^{\mathrm{T}}$ and other Halobacillus species (except for $H$. campisalis). Differences in the peptidoglycan types within the same genus have been shown in some genera (Schleifer \& Kandler, 1972; Takeuchi \& Hatano, 1998; Rheims et al., 1999; Abd El-Rahman et al., 2002).

Strain ISL- $50^{\mathrm{T}}$ exhibited DNA-DNA relatedness values of 9-22\% with respect to the type strains of 13 recognized Halobacillus species: $H$. campisalis ASL- $17^{\mathrm{T}}(19 \%), H$. halophilus KCTC $3685^{\mathrm{T}}(22 \%)$, H. litoralis KCTC $3687^{\mathrm{T}}$ (13\%), H. trueperi KCTC $3686^{\mathrm{T}}$ (15\%), H. karajensis DSM $14948^{\mathrm{T}}(9 \%)$, H. salinus HSL-3 ${ }^{\mathrm{T}}(17 \%)$, H. locisalis MSS$155^{\mathrm{T}}(15 \%)$, H. yeomjeoni MSS- $402^{\mathrm{T}}(20 \%), H$. aidingensis JCM $12771^{\mathrm{T}}(11 \%), H$. dabanensis JCM $12772^{\mathrm{T}}(18 \%), H$. profundi DSM $18394^{\mathrm{T}}$ (14\%), H. kuroshimensis DSM $18393^{\mathrm{T}}$ $(9 \%)$ and $H$. faecis KCTC $13121^{\mathrm{T}}(20 \%)$. These DNA-DNA relatedness values indicate that strain ISL $-50^{\mathrm{T}}$ represents a genomic species that is different from the recognized Halobacillus species (Wayne et al., 1987). Strain ISL-50 ${ }^{\mathrm{T}}$ was differentiated from the recognized Halobacillus species through differences in several phenotypic characteristics, including flagellum type, hydrolysis of substrates, acid production from substrates and the diamino acid type of the cell-wall peptidoglycan (Table 1). The phylogenetic and genetic distinctiveness and differential phenotypic properties are sufficient to categorize strain ISL- $50^{\mathrm{T}}$ within a species that is distinct from the recognized Halobacillus species (Wayne et al., 1987; Table 1). Therefore, on the basis of the data presented, strain ISL- $50^{\mathrm{T}}$ should be placed within the genus Halobacillus as a novel species, for which the name Halobacillus seohaensis sp. nov. is proposed.

\section{Description of Halobacillus seohaensis sp. nov.}

Halobacillus seohaensis (seo.ha.en'sis. N.L. masc. adj. seohaensis of Seohae, the Korean name for the Yellow Sea in Korea, from which the type strain was isolated).

Cells are rods $(0.5-0.9 \times 1.0-4.0 \mu \mathrm{m})$ on MA supplemented with $6 \%(\mathrm{w} / \mathrm{v}) \mathrm{NaCl}$ at $37{ }^{\circ} \mathrm{C}$. Gram-positive, but Gramvariable in old cultures. Motile by means of a single polar flagellum. Colonies are circular, raised, smooth, glistening, yellowish-white in colour and $1.5-2.0 \mathrm{~mm}$ after 7 days incubation at $37{ }^{\circ} \mathrm{C}$ on MA supplemented with $6 \%(\mathrm{w} / \mathrm{v})$ $\mathrm{NaCl}$. Optimal growth temperature is $37^{\circ} \mathrm{C}$; growth occurs at 4 and $38^{\circ} \mathrm{C}$, but not at $39^{\circ} \mathrm{C}$. Optimal pH for growth is 7.0-8.0; growth occurs at $\mathrm{pH} 6.0$, but not at $\mathrm{pH} 5.5$. Optimal growth occurs in the presence of approximately 


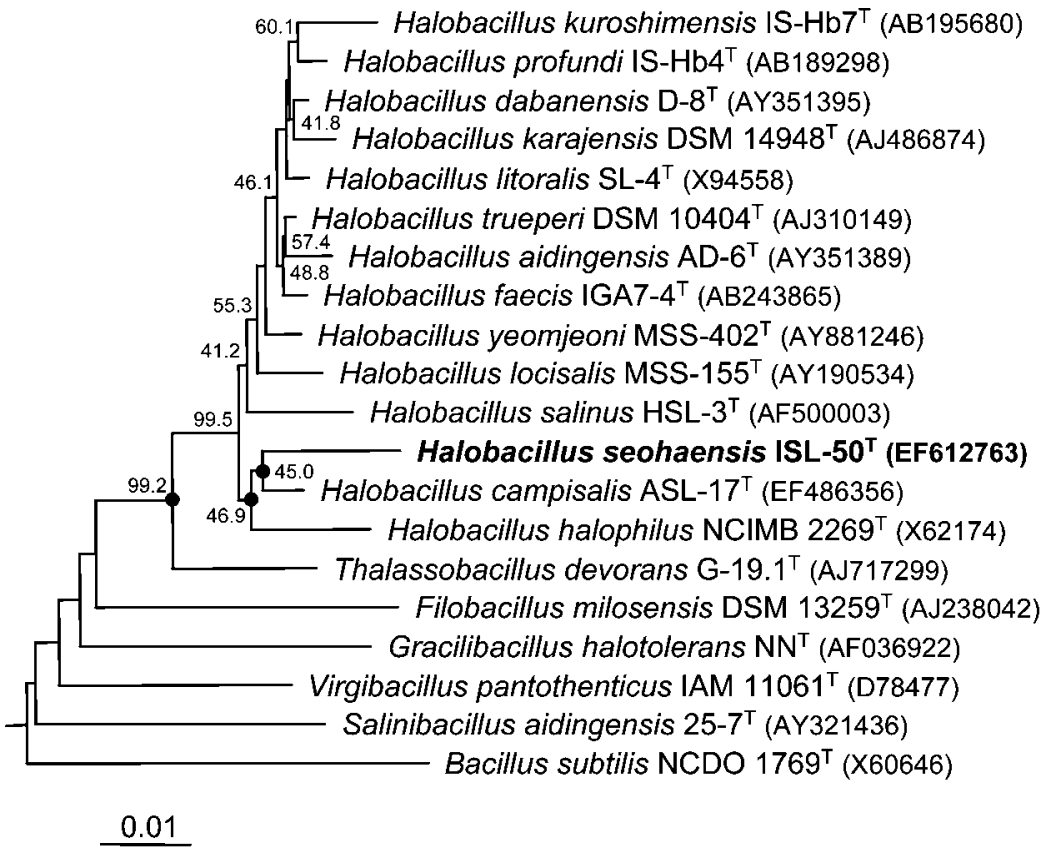

Fig. 1. Neighbour-joining phylogenetic tree based on 16S rRNA gene sequences, showing the positions of strain ISL- $50^{\top}$, other Halobacillus species and some other related taxa. Bootstrap values (expressed as percentages of 1000 replications) $>40 \%$ are shown at branch points. indicates that the corresponding nodes were also recovered in trees generated with the maximum-likelihood and maximum-parsimony algorithms. Alicyclobacillus acidocaldarius DSM $446^{\top}$ (GenBank accession no. X60742) was used as an outgroup (not shown). Bar, 0.01 substitutions per nucleotide position.
$8 \%(\mathrm{w} / \mathrm{v}) \mathrm{NaCl}$; growth occurs in the presence of $1-21 \%$ $(\mathrm{w} / \mathrm{v}) \mathrm{NaCl}$. Tweens 20, 40 and 60, hypoxanthine and xanthine are not hydrolysed. In assays with the API ZYM system, esterase (C4), esterase lipase (C8) and acid phosphatase are present, but alkaline phosphatase, lipase (C14), leucine arylamidase, valine arylamidase, cystine arylamidase, trypsin, $\alpha$-chymotrypsin, naphthol-ASBI-phosphohydrolase, $\alpha$-galactosidase, $\beta$-galactosidase, $\beta$-glucuronidase, $\alpha$-glucosidase, $\beta$-glucosidase, $N$-acetyl $\beta$ glucosaminidase, $\alpha$-mannosidase and $\alpha$-fucosidase are absent. L-Malate is utilized, but L-arabinose, D-cellobiose, D-fructose, D-galactose, D-glucose, maltose, D-mannose, sucrose, trehalose, D-xylose, acetate, citrate, succinate, benzoate, pyruvate, salicin, formate and L-glutamate are not. Acid is produced from D-cellobiose, D-ribose and Dsorbitol, but not from L-arabinose, lactose, D-mannose, melezitose, melibiose, raffinose, L-rhamnose or myo-inositol. Susceptible to ampicillin, carbenicillin, cephalothin, chloramphenicol, gentamicin, kanamycin, lincomycin, novobiocin, oleandomycin, penicillin $\mathrm{G}$ and tetracycline, but not to neomycin, polymyxin B or streptomycin. The cell-wall peptidoglycan contains meso-DAP as the diamino acid. The predominant menaquinone is MK-7. The major fatty acids ( $>10 \%$ of total fatty acids) are anteiso- $\mathrm{C}_{15: 0}$ and anteiso- $\mathrm{C}_{17: 0}$. The DNA G+C content is $39.3 \mathrm{~mol} \%$.

The type strain, ISL $-50^{\mathrm{T}} \quad\left(=\mathrm{KCTC} \quad 13145^{\mathrm{T}}=\mathrm{CCUG}\right.$ $54358^{\mathrm{T}}$ ), was isolated from a marine solar saltern of the Yellow Sea at Byunsan, Korea.

\section{Acknowledgements}

This work was supported by the 21C Frontier Program of Microbial Genomics and Applications (grant MG05-0401-2-0) and the Support and Application Project of Biological Resources (grant
M10508050004-06N0805-00410) from the Ministry of Science and Technology (MOST) of the Republic of Korea. We are grateful to Dr Peter Schumann (Identification Service of the DSMZ) for analysing the cell-wall peptidoglycan.

\section{References}

Abd El-Rahman, H. A., Fritze, D., Sproer, C. \& Claus, D. (2002). Two novel psychrotolerant species, Bacillus psychrotolerans sp. nov. and Bacillus psychrodurans sp. nov., which contain ornithine in their cell walls. Int J Syst Evol Microbiol 52, 2127-2133.

Amoozegar, M. A., Malekzadeh, F., Malik, K. A., Schumann, P. \& Spröer, C. (2003). Halobacillus karajensis sp. nov., a novel moderate halophile. Int J Syst Evol Microbiol 53, 1059-1063.

An, S.-Y., Asahara, M., Goto, K., Kasai, H. \& Yokota, A. (2007a). Terribacillus saccharophilus gen. nov., sp. nov. and Terribacillus halophilus sp. nov., spore-forming bacteria isolated from field soil in Japan. Int J Syst Evol Microbiol 57, 51-55.

An, S.-Y., Kanoh, K., Kasai, H., Goto, K. \& Yokota, Y. (2007b). Halobacillus faecis sp. nov., a spore-forming bacterium isolated from a mangrove area on Ishigaki Island, Japan. Int J Syst Evol Microbiol 57, 2476-2479.

Baumann, P. \& Baumann, L. (1981). The marine Gram-negative eubacteria: genera Photobacterium, Beneckea, Alteromonas, Pseudomonas, and Alcaligenes. In The Prokaryotes, pp. 1302-1331. Edited by M. P. Starr, H. Stolp, H. G. Trüper, A. Balows \& H. G. Schlegel. Berlin: Springer.

Bruns, A., Rohde, M. \& Berthe-Corti, L. (2001). Muricauda ruestringensis gen. nov., sp. nov., a facultatively anaerobic, appendaged bacterium from German North Sea intertidal sediment. Int $J$ Syst Evol Microbiol 51, 1997-2006.

Claus, D., Fahmy, F., Rolf, H. J. \& Tosunoglu, N. (1983). Sporosarcina halophila sp. nov., an obligate, slightly halophilic bacterium from salt marsh soils. Syst Appl Microbiol 4, 496-506.

Cohen-Bazire, G., Sistrom, W. R. \& Stanier, R. Y. (1957). Kinetic studies of pigment synthesis by nonsulfur purple bacteria. J Cell Comp Physiol 49, 25-68. 
Cowan, S. T. \& Steel, K. J. (1965). Manual for the Identification of Medical Bacteria. London: Cambridge University Press.

Ezaki, T., Hashimoto, Y. \& Yabuuchi, E. (1989). Fluorometric deoxyribonucleic acid-deoxyribonucleic acid hybridization in microdilution wells as an alternative to membrane filter hybridization in which radioisotopes are used to determine genetic relatedness among bacterial strains. Int J Syst Bacteriol 39, 224-229.

Hua, N.-P., Kanekiyo, A., Fujikura, K., Yasuda, H. \& Naganuma, T. (2007). Halobacillus profundi sp. nov. and Halobacillus kuroshimensis sp. nov., moderately halophilic bacteria isolated from a deep-sea methane cold seep. Int J Syst Evol Microbiol 57, 1243-1249.

Komagata, K. \& Suzuki, K. (1987). Lipid and cell-wall analysis in bacterial systematics. Methods Microbiol 19, 161-207.

Lanyi, B. (1987). Classical and rapid identification methods for medically important bacteria. Methods Microbiol 19, 1-67.

Leifson, E. (1963). Determination of carbohydrate metabolism of marine bacteria. J Bacteriol 85, 1183-1184.

Liu, W. Y., Zeng, J., Wang, L., Dou, Y. T. \& Yang, S. S. (2005). Halobacillus dabanensis sp. nov. and Halobacillus aidingensis sp. nov., isolated from salt lakes in Xinjiang, China. Int J Syst Evol Microbiol 55, 1991-1996.

Nunes, I., Tiago, I., Pires, A. L., da Costa, M. S. \& Veríssimo, A. (2006). Paucisalibacillus globulus gen. nov., sp. nov., a Gram-positive bacterium isolated from potting soil. Int J Syst Evol Microbiol 56, 1841-1845.

Rheims, H., Fruhling, A., Schumann, P., Rohde, M. \& Stackebrandt, E. (1999). Bacillus silvestris sp. nov., a new member of the genus Bacillus that contains lysine in its cell wall. Int J Syst Bacteriol 49, 795-802.

Rhuland, L. E., Work, E., Denman, R. F. \& Hoare, D. S. (1955). The behaviour of the isomers of $\alpha, \varepsilon$-diaminopimelic acid on paper chromatograms. J Am Chem Soc 77, 4844-4846.

Sasser, M. (1990). Identification of bacteria by gas chromatography of cellular fatty acids, Technical Note 101. Newark, DE: MIDI.

Schleifer, K. H. \& Kandler, O. (1972). Peptidoglycan types of bacterial cell walls and their taxonomic implications. Bacteriol Rev 36, 407-477.

Soto-Ramírez, N., Sánchez-Porro, C., Rosas-Padilla, S., Almodóvar, K., Jiménez, G., Machado-Rodríguez, M., Zapata, M., Ventosa, A. \& Montalvo-Rodríguez, R. (2008). Halobacillus mangrovi sp. nov., a moderately halophilic bacterium isolated from the black mangrove Avicennia germinans. Int J Syst Evol Microbiol 58, 125-130.
Spring, S., Ludwig, W., Marquez, M. C., Ventosa, A. \& Schleifer, K.-H. (1996). Halobacillus gen. nov., with descriptions of Halobacillus litoralis sp. nov. and Halobacillus trueperi sp. nov., and transfer of Sporosarcina halophila to Halobacillus halophilus comb. nov. Int J Syst Bacteriol 46, 492-496.

Staley, J. T. (1968). Prosthecomicrobium and Ancalomicrobium: new prosthecate freshwater bacteria. J Bacteriol 95, 1921-1942.

Takeuchi, M. \& Hatano, K. (1998). Proposal of six new species in the genus Microbacterium and transfer of Flavobacterium marinotypicum ZoBell and Upham to the genus Microbacterium as Microbacterium maritypicum comb. nov. Int J Syst Bacteriol 48, 973-982.

Tamaoka, J. \& Komagata, K. (1984). Determination of DNA base composition by reversed-phase high-performance liquid chromatography. FEMS Microbiol Lett 25, 125-128.

Wayne, L. G., Brenner, D. J., Colwell, R. R., Grimont, P. A. D., Kandler, O., Krichevsky, M. I., Moore, L. H., Moore, W. E. C., Murray, R. G. E. \& other authors (1987). International Committee on Systematic Bacteriology. Report of the ad hoc committee on reconciliation of approaches to bacterial systematics. Int J Syst Bacteriol 37, 463-464.

Yoon, J.-H., Kim, H., Kim, S.-B., Kim, H.-J., Kim, W. Y., Lee, S. T., Goodfellow, M. \& Park, Y.-H. (1996). Identification of Saccharomonospora strains by the use of genomic DNA fragments and rRNA gene probes. Int J Syst Bacteriol 46, 502-505.

Yoon, J.-H., Lee, S. T. \& Park, Y.-H. (1998). Inter- and intraspecific phylogenetic analysis of the genus Nocardioides and related taxa based on 16S rDNA sequences. Int J Syst Bacteriol 48, 187-194.

Yoon, J.-H., Kang, K. H. \& Park, Y.-H. (2003). Halobacillus salinus sp. nov., isolated from a salt lake on the coast of the East Sea in Korea. Int J Syst Evol Microbiol 53, 687-693.

Yoon, J.-H., Kang, K. H., Oh, T.-K. \& Park, Y.-H. (2004). Halobacillus locisalis sp. nov., a halophilic bacterium isolated from a marine solar saltern of the Yellow Sea in Korea. Extremophiles 8, 23-28.

Yoon, J.-H., Kang, K. H., Oh, T.-K. \& Park, Y.-H. (2005). Halobacillus yeomjeoni sp. nov., isolated from a marine solar saltern in Korea. Int $J$ Syst Evol Microbiol 55, 2413-2417.

Yoon, J.-H., Kang, S.-J., Jung, Y.-T. \& Oh, T.-K. (2007). Halobacillus campisalis sp. nov., containing meso-diaminopimelic acid in the cellwall peptidoglycan, and emended description of the genus Halobacillus. Int J Syst Evol Microbiol 57, 2021-2025. 